\title{
Cikkismertetés: A haldokló baktériumok lehetővé teszik a növekedést és a túlélést mások számára antimikrobiális vegyületek felszívásával ${ }^{1}$
}

\author{
Article review: Dying bacteria allow others to survive and grow by absorbing \\ antimicrobial compounds
}

Ismertető: $\quad$ Gajdács Márió $\bowtie$

Szegedi Tudományegyetem Általános Orvostudományi Kar, Klinikai Mikrobiológiai
Diagnosztikai Intézet

Ismertetett cikk: Mehdi Snoussi, John Paul Talledo, Nathan-Alexander Del Rosario, Salimeh Mohammadi, Bae-Yeun Ha, Andrej Košmrlj, Sattar Taheri-Araghi: Heterogeneous absorption of antimicrobial peptide LL37 in Escherichia coli cells enhances population survivability. eLife 2018;7:e38174. doi: 10.7554/eLife.38174.001

Beküldve: $\quad$ 2019. 02. 22.

doi: $\quad 10.24365 /$ ef.v60i2.426

Kulcsszavak: antibiotikum; antimikrobiális peptid; rezisztencia; önfeláldozás; kísérlet

Keywords: antibiotic; antimicrobial peptide; resistance; sacrifice; experiment

A kórokozó baktériumok számos stratégiával rendelkeznek az antibiotikumok pusztító hatásának túlélésére: rezisztenciájukat többféle molekuláris mechanizmuson keresztül képesek kifejezni (többek között a szer lebontása, kipumpálása vagy a célpontjának megváltoztatása mutációk által), vagy biofilmekbe ágyazva élik túl a gyógyszerek hatását. A Princeton és a Kalifornia Állami Egyetem (CSUN) kutatóinak új eredményei rávilágítottak egy újabb lehetséges mechanizmusra: az önfeláldozásra a baktériumpopuláción belül.

Az antimikrobiális peptidek (AMP-k) természetes aminosav-alapú antibiotikumok, amelyek a többsejtű élőlények kórokozók elleni első védelmi vonalának részét képezik. Az AMP-k antibakteriális hatásmechanizmusának jellemzői a fizikai kölcsönhatásokban keresendők. Az AMP-k struktúrái két közös szerkezeti motívummal rendelkeznek: a kationos töltés és amfifil kémiai tulajdonság, amelyek a bakteriális sejtmembránnal létrejövő kölcsönhatásban játszanak szerepet. A kutatás során egy adott antimikrobiális peptiddel kezelt Escherichia coli baktériumok populációjára vonatkozóan a kutatók megállapították, hogy egyes haldokló sejtek nagy mennyiségben felszívják az antibiotikumot, lehetővé téve a szomszédos sejtek életben maradását és továbbnövekedését. A kutatók létrehozták az érdekelt antimikrobiális molekula módosított, zöld fluoreszcens változatát, az LL37 néven ismert peptidmolekulát, amelyet természetes körülmények között az emberi bőr, a légutak és más olyan szervek termelnek, amelyek gyakran érintkeznek a külső környezet baktériumaival. A fluoreszcens molekula mozgásának eszközös nyomon követése a baktériumpopuláción keresztül azt mutatta, hogy az 
antibakteriális hatással rendelkező molekula az elpusztult sejtek egy részében felhalmozódott, és dichotóm eloszlást eredményezett a baktériumsejtek között. A nagy sejtsűrúségú tenyészetekben két különböző alpopuláció jelent meg: egy nem növekedő/elpusztult populáció, amely mintegy felszívta a peptideket, illetve egy növekvő populáció, amely képes volt túlélésre, mert az AMPket más fajtársaik kötötték meg. Ez a sejtpopulációk közötti átmenet valószínúbb volt a sejtosztódási ciklusok késői szakaszában.

\begin{abstract}
A kísérletet követően a kutatók kollaboráció keretében matematikai modellt is kidolgoztak a jelenség részletesebb magyarázatához. A modell az eltérő denzitású baktériumpopulációk kinetikáját írja le a különböző koncentrációjú antibakteriális szerekkel szemben: bemutatja, hogy az elpusztult sejtek magukon belül izolálják a veszélyes molekulákat, így biztosítják és előre jelzik a túlélő (perzisztáló) sejtek megjelenését és fennmaradását. Az új jelenség (amelyet a szerzők „passzív kooperációnak” neveztek el) felismerése fontos lépés, azonban továbbra is nyitott a kérdés, hogy molekuláris szinten mi is történik pontosan, ami kiváltja ezt az önfeláldozó mechanizmust.
\end{abstract}

\section{TANULSÁGOK A HAZAI SZAKEMBEREK SZÁMÁRA}

Az antibiotikum-rezisztencia globális szinten súlyos egészségügyi problémát jelent, a rezisztens kórokozók kialakulását elősegíti a nem megfelelő (szub-inhibitoros) dózisban és ideig alkalmazott terápia. Az ismertetett kísérletes közlemény alátámasztja az antibakteriális szerek megfelelő dózisú adagolásának szükségességét (a már létező antibiotikumok klinikai alkalmazását), hiszen kimutattak egy olyan további mechanizmust, amellyel a kórokozók képesek túlélni a sokszor életmentő gyógyszerek hatását. A cikk emellett számos olyan kérdést vet fel, amelynek jelentős következményei lehetnek új antibiotikumok tervezésében.

\section{KÖSZÖNETNYILVÁNITT́́S}

A közlemény létrejöttét az NTP-NFTÖ-18-C-0225 „Nemzet Fiatal Tehetségeiért Ösztöndíj” támogatta.

\section{HIVATKOZÁSOK}

${ }^{1}$ https://elifesciences.org/articles/38174 